\author{
Radosław Sztyber \\ Uniwersytet Zielonogórski
}

\title{
Wokół wybranych propozycji nazewniczych Dembołęckiego w świetle idei Wywodu jedynowlasnego państwa świata
}

Bohater tytułowy szkicu nieomal odruchowo kojarzony jest z najbardziej kuriozalnymi pomysłami spod znaku najszerzej rozumianej lingwistyki. Między innymi z myślą o tym siedemnastowiecznym pisarzu Julian Tuwim precyzował dziedzinę osiagnięć księdza Wojciecha i znacząco oceniał:

żadna gałąź wiedzy nie obrosła taką obfitością przysłowiowych gruszek na wierzbie i niebieskich migdałów co językoznawstwo, a zwłaszcza ten dział językoznawstwa, który się najbardziej do fantazji i fabulizowania nadaje, a mianowicie etymologia [Tuwim 1950: 330].

W zbliżonym duchu, choć surowiej, wypowiedziała się J. Puzynina:

zarówno same teorie Dembołęckiego, jak i jego metoda „naukowa” mówią same za siebie i nie potrzebują wielu komentarzy. Należą one do najgorszych tradycji postawy wobec języka ojczystego i godne są przypomnienia jedynie jako wymowny przykład tego, do czego mogła doprowadzić katolicko-szlachecka ideologia XVII wieku, zbratana z ciemnotą i zarozumiałością [Puzynina 1955: 377].

Przywołane opinie odnoszą się oczywiście do Wywodu jedynowłasnego państwa świata, książki drukowanej po raz pierwszy w 1633 roku w Warszawie [Dembołęcki 2012]. Właśnie z powodu tego niezwykłego traktatu historiozoficznego jego autor doczekał się wielu nagan jużu współczesnych, ponadto krytykę wzmagał sobiepański tryb życia krnąbrnego franciszkanina, zwanego przez konfratrów zakonnych „bratem wagabundą" [Kochańska 1956: 129]. Tych kilka przypomnień niech posłuży za punkt wyjścia do dalszych rozważań, które jednak trzeba będzie wyposażyć w dopowiedzenia innej natury, ponieważ dość powszechnie ośmieszany mnich własnymi łamańcami językowymi nie kompromitował siebie, lecz piętnował zwłaszcza adresata utworu, przesadnie ambitną i średnio wyrobioną intelektualnie herbową rzeszę. Odbiorcę tekstu dobitnie scharakteryzowała wspomniana już J. Puzynina.

Dembołęcki pisze wyraźnie na zamówienie szlacheckie. Głupiej, ciemnej i pełnej szowinizmu szlachcie XVII w. bardzo mogły odpowiadać megalomańskie genealogie narodu polskiego 
i warstwy szlacheckiej, odciętej nieprzekraczalną granicą pochodzenia od innych stanów, podobnie jak i imperialistyczne mrzonki przyszłego panowania nad światem, połączone z zagrzewaniem do aktualnej w tym czasie wojny z Turcją [Puzynina 1955: 377].

\section{Wywód - geneza, przesłania (zasadnicze i skrywane), metoda dowodzenia}

Splot rozmaitych okoliczności zrodził Wywód; wchodzą tu w rachubę uwarunkowania społeczne, kulturowe, polityczne, a nie bez znaczenia okazują się osobowościowe predyspozycje twórcy; przecież ,grabieżcze wyprawy lisowczyków - stwierdzał Jan Stanisław Bystroń - oddał Dębołęcki pod bezpośrednie kierownictwo Boga" [Bystroń 1980: 298; zob. też Sztyber 2011a: 191-209], rzecz jasna, w Przewagach elearów polskich, publikacji starszej od „wywodowej” teorii o dziesięć lat [Dembołęcki 1623]. Potrafił nasz autor „odwracać kota ogonem”, był wyrachowanym agitatorem, wyrafinowanym propagandysta, świadomym grzechów kondotierów ich apologetą [zob. np. Sztyber 2011b: 132-161, 273-290; 1999: 123-142]. Nawet dobrze spetryfikowany mit sarmacki przekształcił i nadał mu nowe miano; jak można wnosić z jego toku myśli, byłby to mit... „carmacki” [Dembołęcki 2012: 281]. Zresztą w traktacie do manipulacji nawet się przyznał; wprawdzie osobiste wyznanie zawarł w postaci szyfru, niemniej wymowa ukrytej konfesji niewątpliwie robi wrażenie. Skierowana jest do Gryzosława [Dembołęcki 2012: 422] i brzmi dość zaskakująco: „Gryź gry, a bij jeno piórkiem, bo nie ufam mojej prawdy pióra" [Sztyber 2010: 42-61].

Inny symptomatyczny sygnał zwodzenia czytelnika wyzyskuje już językową ekwilibrystykę, a właściwie nomenklaturową woltyżerkę. Chodzi o pojmowanie wiedzy o minionym, deprecjonował bowiem Dembołęcki historię, natomiast gloryfikował „istorię”, pierwszy termin łączył się dla duchownego z Konojad z łacińskim rzeczownikiem (histrio) oznaczającym komedianta, trefnisia w znaczeniu właściwym, natomiast przenośnym - pozera, blagiera [por. Dembołęcki 2012: 290; Stownik 1962: 716-717]. Słowem, historia to „błazenada, bajanie, bajdurzenie", objaśnia następnie tę kwestię Z. Ogonowski [1979: 147]. Nie zatem, jak głosi dawna maksyma, nauczycielka życia ilustruje prawdę, ale wyłącznie rzeczona już ,istoria” oddaje ponoć „istą rzecz, jako co było” w rzeczywistości [Dembołęcki 2012: 290] - usiłuje dowieść rodzimy kolorysta. Ciekawe, niemniej zastanawia, dlaczego zasadniczą część rozważań ideologa otwiera odbity sporych rozmiarów czcionką nagłówek - „Wywód historycki” [Dembołęcki 1633: 27 i n. w żywej paginie; Dembołęcki 2012: 335]. Wnioskujmy - ten wywód jest po prostu błazeński. Dodajmy jeszcze - na wyrost i na pokaz, zgodnie z zamiarem brata Wojciecha. 
Dopiero co omówiona sprawa stanowi zaledwie namiastkę lingwistycznych cięć i gięć słownych. Jak widać, wcale istotnych, skoro w rezultacie Dembołęcki mógł występować w roli najwyższego arbitra decydującego o stopniu wiarogodności poszczególnych źródeł dziejopisarskich. A to ważny element w obłudnej strategii perswazyjnej księdza, zapewniającego sobie niemałe pole manewru w procesie uwodzenia czytającej publiczności. Nie od dziś wiadomo, że jakimkolwiek akcjom promocyjnym nie zawsze służy prawda, wielokrotnie intencjonalnie zastępowana przerostem informacyjnym, egzaltacją i przesadą. Na dobrą sprawę, a to zasadnicze przesłanie Wywodu, dawniejszy kapelan lisowczyków wynalazł casus belli, dający narodowi mandat do ekspansji. Tytułem dla tych imperialistycznych zakusów miały być „starożytność” i ,pierwszość” polskiej nacji, rzekomo wywodzącej się od starotestamentowego Adama. Dlatego też ojczystą krucjatę winna usprawiedliwiać uzasadniona wola odzyskania „utraconego”, w wymiarze globalnym - odzyskania władzy nad... światem. Oto cel podstawowy utworu, po trosze prognostyczny, ale i odwołujący się do przeszłości. Dopiero na ostatnim miejscu należy umieścić mowę, gdyż, jak przed kilkudziesięciu laty trafnie pisała M. Kochańska, „u Dembołęckiego zainteresowania językowe pełnią funkcję wyraźnie służebną" [Kochańska 1956: 136]. Tak, serie rozmaitych dziwactw słownych otrzymały rangę przysłowiowej kropki nad ,"' w poszczególnych roztrząsaniach obdarzonego nietuzinkową fantazją księdza Wojciecha.

Wszystkie wytwory językowej wyobraźni autora Wywodu bezsprzecznie wypadają intrygująco, nade wszystko zaś wyróżnia je bijący z nich infantylizm. Niemniej iluzoryczność erudycyjnych dowodów prowadzonych przez polihistora, poliglotę i teologa $\mathrm{z}$ doktoratem $\mathrm{z}$ tej dziedziny, stwierdźmy bez wahania, nakazuje zachowanie dystansu i pożądanego sceptycyzmu [por. Bentkowski 1814: 194]. W sposób cokolwiek zawoalowany zalecał takie podejście sam mistyfikator, o czym już wspomniano. Inne przesłanki traktatowej oferty również skłaniają do głębszego namysłu nad jej ostatecznym kształtem i wydźwiękiem. Gdyby Dembołęcki nas nie oświecił, skąd pochodzimy, nie poznalibyśmy naszych początków. Oto rewelacja niezwykłej próby, a to (uproszczone nieco) cytaty; po pierwsze wywodzimy się od „tyta abo od cyca" [Dembołęcki 2012: 360], po drugie, z Babilonu, więc z „babiego łona” [Dembołęcki 2012: 360]. Umownie odkrywcze, na pewno ucieszne; ale ostatni przykład kojarzy Polaków z jedną z najstarszych cywilizacji, a wtóry zaskarbia godności, siłę i rozmiar Tytanów, naszych przodków.

Tym sposobem wkraczamy w materię toponimicznych fajerwerków Dembołęckiego. Jednak należy je interpretować w zarysowanej pokrótce perspektywie, by ustrzec się przed upraszczającym rzecz odbiorem, poglądowo i odważnie opisanym niedawno przez K. Jurewicza, wydawcy fragmentu Wywodu:

tekst jest [...] właściwie nieznany - czasem niestety również przywołującym go badaczom, cytującym (i niekiedy powtarzającym jeden za drugim choćby błędny tytuł) z ironicznym uśmiechem i politowaniem co bardziej smakowite fragmenty, które - wyrwane z kontekstu - rzeczywiście sprawiają wrażenie dzieła szaleńca. Na sali rozlega się chichot i sprawę Dębołęckiego można zamknąć [Jurewicz 2007: 279]. 
Sprawy tak po prostu zamknąć nie można choćby ze względów już podniesionych. Nowe szczegóły niewątpliwie komplikują odczytanie traktatu, nadają utworowi cechy, a może nawet walory, jakich dotąd był pozbawiony, przynajmniej w większości dotychczasowych lekturowych doświadczeń. Dzięki nim właśnie, tj. omówionym właściwościom Wywodu, w bezkrytycznej na pierwszy rzut oka apoteozie udaje się dostrzec satyrę, płynącą podskórnym nurtem napuszonej i udawanej pochwały.

\section{Językowy stempel jako dowód na prawo Polaków do władania światem i posiadaniem calego globu}

W świetle ukazanych faktów obrany przez zakonnika kurs na modernizację istniejących znaków onomastycznych wydaje się składnikiem zabiegu polegającego na systemowym uwierzytelnianiu tezy o polskiej lub choćby słowiańskiej proweniencji wszystkiego i wszystkich. Wobec takiego stanowiska „odkrywcy” nie mogą dziwić ciągi neologizmów makrotoponimicznych, wskazujących masy kontynentalne. Swojsko brzmiące ich nazwy przytoczmy od razu, bez ich motywacyjnej opoki; są to: Narodyca, Synrodyca i Zobodwica. A to właściwie cała planeta z przytłaczająco większą częścią jego lądowego zasobu. Objaśnienie sensu tych nazw, a przede wszystkim ich genezy, pozostawmy samemu ich twórcy: „Narodyca” (a jej części ponadto otrzymały inne konkurencyjne określenia), „przeto że się w niej narody poczęły”, „Synrodyca”, ,że się tam synowie Narodycy rozrodzili, a trzecią [ziemię] Zobodwica [nazywaja], iże z tych obudwu jest rozkrzewiona". Rozwikłajmy zagadkę tych ciekawych korekt onomastycznych, zbędnych przecież, gdyż i w XVII w. (dokładnie, jak i obecnie) istniały słowne ekwiwalenty jednoznacznie definiujące wskazane obszary. Narodyca - Afryka, Azja i Europa; Synrodyca - obie Ameryki; Zobodwica - Australia.

Ten koncept, bo chyba w takich kategoriach należy traktować omawianą grupę terminów geograficznych, urósł z dawniejszego przeświadczenia zdefiniowanego choćby przez Ludwikę Szczerbicką-Ślęk. Odnotujmy słowa uczonej:

punktem wyjścia wszelkich dociekań etymologicznych - pisze L. Szczerbicka-Ślęk - było przekonanie o niekonwencjonalnym związku między znaczącym i znaczonym. W słowach poszukiwano więc istoty rzeczy. Etymologiczny topos zalecały już antyczne retoryki, za pośrednictwem średniowiecza przejął go renesans i barok [Szczerbicka-Ślęk 1973: 138; por też Curtius 1997: 519-525].

Zgłoszone przez Dembołęckiego korekty wspierają się na jednym z ważniejszych założeń etiologii biblijnej, etymologicznej. „Franciszkaniec”, jak o bracie Wojciechu wyraził się ks. prof. Stanisław Celestyn Napiórkowski, wyraźnie tę zasadę wyłożył w samym traktacie. I tym razem oddajmy głos niezwykłemu autorowi. 
Jadam swe syny, jako i oni swoje potomki, także góry, lasy, krainy, rzeki i insze rzeczy takiemi słowami przezywali, jakich abo czas, abo dzieła jakie wyciaggały. Stądże w Biblijej pełno mamy przyczyn, dla których komu jakie imię było dane abo co przezwanego [...]. To abowiem za fundament wziąwszy, jawno jest, że i w samych słowach dobrze zrozumianych dyszy niemal wszystka prawda.

Tok rozumowania wyzyskuje jeszcze, warto uzupełnić, głośny werset starotestamentowy, pochodzący z pierwszej księgi starozakonnej i rekonstruujący inicjalny proces nadawania elementom bytu imion [por. Dembołęcki 2012: 296]. Sprawcą tego przedsięwzięcia był mężczyzna stworzony przez Boga. Zapewne używał narzędzi powszechnych w komunikacji, mianowicie słów, stąd nazwa języka, jakim się posłużył: „słowieński” - domyślił się nasz wizjoner. Dlatego też, dalej oryginalnie spekuluje Dembołęcki, Adam musiał przynależeć do rodziny plemion zamieszkujących obecnie zwłaszcza środkowo-wschodnie tereny Starego Kontynentu. A to region Narodycy, gdzie - tu z kolei najpewniej ksiądz zmierza tropem J. Flawiusza interpretującego stosowne perykopy pism natchnionych - tworzyły się zalążki poszczególnych nacji [por. np. Flawiusz 2001: 109-115]. W obu przykładach obserwujemy konkretne wdrożenie omówionej zasady, powtórzmy, łączącej znaczące ze znaczonym.

Znakomicie tę regułę widać w przypadku imion osób znanych z pierwszej księgi pomników wiary. Nie satysfakcjonują Polaka patrioty rozstrzygnięcia w tej materii, mimo iż je świetnie zna (s. 327), ogłoszone przez mistrzów egzegezy tej miary, co św. Hieronim [1884, szp. 825-826] czy Izydor z Sewilli [1911: ks. 7, 6, 13]. Co prawda, uzgadnia je $z$ autorytetami, ale na rodzimą modłę przekształca. Abel to „Ubeł, gdy go Kaim zabił” [Dembołęcki 2012: 328], Matuzalem, a właściwie w nowym, ojczystym kostiumie Mątuściąłoch - ,stąd beł tak przezwany, że Kainijany wysiekł, którzy i przed potopem długiemi wojnami świat mącili, stądże go wykładają mittens mortem abo apostolus mortis" [Dembołęcki 2012: 328]. Nie inaczej z Malahaleelem (Malaleelem). W nowym wcieleniu objawił się zjawiskowo jako Molaleł - „dlatego tak beł rzeczony, że pierwszy na świecie Kainijany podbił, którzy jako mol wszystek naród ludzki psowali" [Dembołęcki 2012: 328].

Z tej szlachetnej i, jak widać, walecznej, nadto skutecznej militarnie linii, biorącej swój początek od trzeciego prawowiernego syna Adama, mianowicie Seta, wywodził się jeden z naszych najwybitniejszych protoplastów, potomek Noego - Jafet [Dembołęcki 2012: np. 333]. To od niego krajanie szczycili się nadzieją na panowanie i triumf w posłudze rycerskiej, „w myśl sloganu: »Tu Sem ora, Cham labora, Iaphet rege et protege«" [Puzynina 1955: 368]. I w imieniu tegoż praszczura rodaków znad Wisły Dembołęcki również dostrzegł potencjał, umożliwiający zjednoczenie go z mianem... Czarnego Lądu. „Odpsowana”, tj. odtworzona forma wyrazu otrzymała postać niewątpliwie ciekawa, mianowicie ,Jawrucę" [Dembołęcki 2012: 363], z której dzięki kilku operacjom fonetycznym można uzyskać odpowiednik lingwistyczny adekwatny dla Afryki. Wystarczy dokonać kilku modyfikacji, możliwych zresztą w niektórych, uzasadnionych przypadkach 
- usunięcie ,joty”, ,a" bez zmian, pozbawienie dźwięczności „w”, „u” to „y”, „c" i ,e”" w obu wypadkach nieomal jednakowe dzięki fleksyjnym prawidłom i przypadkowej akurat zbieżności. Dość przejrzyste, ale i zabawne. Tak czy inaczej - zagarnęliśmy Afrykę, wyłącznie słowem, bez użycia oręża, bezkrwawo, jak na biesiadzie nieraz Sarmaci pogrążali animuszem wzmocnionym trunkiem wielkie imperia - pisał z przekąsem K. Opaliński [por. Opaliński 1953: 210].

Dodajmy także - i faraonowie, zaglądając w lustra, radowali swoje oczy słowiańskimi rysami, w końcu najwyższego władcę Egiptu miał identyfikować rzeczownik zrodzony ponoć z wyrażenia „'waruj się go"”, co z czasem urosło do „warahon”, a następnie ludzie „popsowali” tę postać leksemu i nadali mu brzmienie znane do dziś [Dembołęcki 2012: 365]. Nie tylko obszar dawnej Libii (tj. Afryki) językowo anektował Dembołęcki. Identycznie uczynił z terenami na wschód od Uralu, ogłaszał: to Ożyja, tak „rzeczonej, że w niej stworzona wszelka rzecz żywiąca i po potopie znowu 'ożyła" [Dembołęcki 2012: 362]. Czas na najbliższy nam region, odkrywca onomastycznych sprzeniewierzeń korygował - Uroba, „to jest “wyrobiona”, bo najdawniejsza, choć potem „wypsowano Europa" [Dembołęcki 2012: 391]. Wszystko za sprawą najistotniejszego w Wywodzie ojczystego antenata, ósmego ,pana świata”, mianowicie wieloimiennego Goga-Polacha-Polluksa. Wcześniej, insynuuje nasz dysponent dziwacznych prawd, o kontynencie tym mówiono Neuroba, ,jakoby 'niewyrobiona" [Dembołęcki 2012: 391]; za tę nieudolną sugestię onomastyczną odpowiedzialność miał ponosić jeden z braci Goga, czyli Gomer, kolejny syn Jafeta. Nowy Świat również otrzymał ciekawą notę; wiemy, że to Synrodyca albo Synrodia [Dembołęcki 2012: 364], niemniej Dembołęcki aprobował pozostające w powszechnym użyciu osiagnięcia dawnych i współczesnych chorografów, dlatego zaakceptował znany stempel językowy Ameryk. Uznał wszakże, iż wśród rodzeństwa Magoga znalazł się nieomal imiennik Vespucciego - Amaroch, „zagnany” daleko na zachód od Starego Świata. A trafił tam, godzi się dopowiedzieć, wschodnim szlakiem [Dembołęcki 2012: 371], no i przed Kolumbem.

Tendencję duktu tego rodzaju zawłaszczeń, potwierdzanych raz po raz iluzorycznym autorytetem lingwistycznej niejako oczywistości, zakonny brat obrazowo i symptomatycznie ujął w enucjacji co najmniej efektownej - obcy naród, przecież nie my, pramowę , wygrzecznił na greczyznę abo [...] wyłacnił na łacinę, abo jakokolwiek inaczej [...] wyforemnił" [Dembołęcki 2012: 305]. Wiadomo, kto - Grecy, łacinnicy, ale też i użytkownicy ,żydowizny" [Dembołęcki 2012: np.: 301, 303, 304], jak się wyraził nasz siedemnastowieczny pisarz. Pokłosie tych czasów błędów i wypaczeń postanowił wybiórczo naprawić ksiądz znad Wisły, przy czym, co raczej dość kontrowersyjne, dopiero co wynotowane z Wywo$d u$ zdanie okazuje się może nie dosłownym plagiatem, choć plagiatem myśli na pewno, wszakże bezsprzecznie jest parafrazą sformułowania ogłoszonego około pół wieku wcześniej przez głośnego Johannesa Goropiusa Bekanusa [Bekanus, 1580, Gallica, ks. 4: 110], którego awanturniczy mnich w traktacie skrytykował 
[Dembołęcki 2012: 304-305], a mimo to naśladował, niekiedy wręcz niewolniczo [por. Jurewicz 2007: 309: przyp. 78], choć na polską modłę [Sztyber 2012a: 215-226]. Jedno dopowiedzenie - wspomnianemu Belgowi kultura powszechna zawdzięcza teorię, wspartą m.in. na filarach językowych dociekań, że to mieszkańcy okolic Antwerpii posługiwali się najstarszą leksyką i w następstwie stanowili pierwszą nację świata. W sukurs Brabantczykowi np. przyszło imię ofiary Kaina - Abel. Jeden przykład. Krótko: zmierzajmy tropem dowodzenia Bekanusa - usuńmy inicjalną samogłoskę „a”, a funkcję „formantu” nadajmy literze „g”. Wynik — Belg [Bekanus 1569: 541].

Dembołęcki dokonał jeszcze jednego werbalnego podboju. Tym razem skupił uwagę na raju (niczym antwerpczyk). Wypada poczynić kolejne ważne uzupełnienie - nie z Sarmatów idziemy, ale Scytów [Dembołęcki 2012: np. 279]. Taka wolta genealogiczna gwarantowała palmę pierwszeństwa Polaków, gdyż - a to sprawa szczególnie istotna w całej wymyślonej koncepcji z 1633 roku - ci Scyci mieli być bezpośrednimi potomkami Seta-Scyta (bo to jedna osoba!), co duchowny uzasadniał bliskością brzmieniową tych dwu mian [Dembołęcki 2012: np. 282, 317]. Dowód wyzyskiwał, jak widać, językową supozycję, obróconą w pewnik, oraz nadzieje na pozyskanie dziejów sławnego ludu opisanego przez Herodota czy Marka Junianusa Justynusa. W relacji tego ostatniego, opracowanej na podstawie tekstu Pompejusza Trogusa, wyczytać można deskrypcję Scytii [Justynus 1988: 15 i przyp. 4]. Ojciec Wojciech zaś dopatrzył się w niej kalki z Księgi Rodzaju (2, 8-14), odbijającej położenie ziemskiego dziedzictwa Adama i Ewy, nadanego im, a następnie odebranego przez Boga.

Zatem protoplastka Rzeczypospolitej winna leżeć w... biblijnym „miejscu rozkoszy", jak o raju czytamy w Starym Testamencie. Pismo Święte w odpowiednim wersecie wskazuje cztery rzeki identyfikujące omawianą przestrzeń; co do dwóch nie ma wątpliwości, to Tygrys i Eufrat. Pozostała para to Pison (Fizon) i Gehon. Jednak Dembołęcki wie... najlepiej. Oto kilka niespodzianek onomastycznych wraz z ich fundamentem językowej i chyba zwłaszcza pozajęzykowej inspiracji. Nadinterpretacjom traktatopisarza trzeba zresztą przypisać właściwość dominującej metody badania, wspieranej bądź zamykanej nieomal ekstrawagancką puentą lingwistyczną, stronniczo koherentną z dziejowym nurtem rekonstrukcji Wywodu. Pison (u Wujka: Fison, ale także w Biblii Tysiąclecia: Piszon), to... Ganges, choć, jak dowiadujemy się od dawniejszego kapelana wojskowego, ta płynąca woda powinna zwać się „Wyżonem, jakoby miejscem wygnania”, niemniej inni zwą ją „Gangesem” zamiast „Gongesem”, też niby słusznie, ,jakoby miejscem, gdzie goniono on giez rozegżonych Kainijanów”. Teraz pochylmy się nad Gehonem - ,to jest Nil, dlategoż też [ta rzeka] nabeła imienia Gon, z którego Żydzi uczynili Gehon, bo daleko za Nil ostatki Kainijanów po Afryce goniono". Naprawdę interesujące... Ale tym koniekturom nie brakuje nacjonalnie krojonych uzurpacji, z zamierzoną egzageracją [Dembołęcki 2012: 344-345]. 
Zarazem nie sposób pominąć faktu, że „brat wagabunda” dane te wydobył ze studiowanych źródeł, mowa o próbach utożsamień hydrologicznych fenomenów. Takie same rozpoznania w kwestii identyfikacji wspomnianych rzek prezentował znacznie wcześniej J. Flawiusz [2001: 103], następnie powtarzał dziejopisarski mistrz Dembołęckiego Gilbert Genebrard [1599: 7]. Po prostu wiele wydawałoby się absolutnie ewidentnych niedorzeczności Wywodu znajduje potwierdzenie w rozmaitych pracach. Na przykład: polskiemu duchownemu udało się ustalić imię żony Jafeta, zmilczane w Księdze Rodzaju. To... Wanda, chyba ta, „co Niemca nie chciała”. Insynuacja intrygująca, ale nieoryginalna, ponieważ pochodzi z kronikarskiego dzieła Hartmanna Schedla z końca XV w., gdzie obok syna Noego sportretowano jego połowicę, a rycinę wyposażono w deskrypcję: „Funda uxor" [Schedel 1493: XVI r.]. Rola historiozofa ograniczyła się tym samym do wyekscerpowania stosownej wiadomości i, co najbardziej wątpliwe w zakresie metodologicznych nadużyć, zinterpretowania sprawy zgodnie ze sfabrykowaną koncepcją. Dostrzeżona cecha traktatu nakazuje surowszą postawę wobec dobrze wykształconego i oczytanego autora, który snuł swoją opowieść, jak się okazuje, nie bez wyrafinowania i w zamian za rzetelną prawdę podsuwał odbiorcy serie polonofilskich konfabulacji.

Wróćmy jednak do ,rajek”, tj. rajskich rzek, jak sugerował mnich, by je nazywać poprawnie. Rodowód językowego znaku Tygrysu etymolog ujął następująco: „Tagrodź, jakoby przegroda”, dopowiedzmy, „od wyrodztwa Kaimowskiego”; Eufrat zaś - rzeka ta „tak barzo na koło idzie, iż wyszedszy z źrzódła swego między północy a zachód kołem wypada na południe, stądże nazwany 'obrotem' abo 'owrotem"” [Dembołęcki 2012: 343-344]. Również i pasmo górskie Taurus otrzymało czytelne objaśnienie, sięgające sensów skoncentrowanych wokół jednego z założycielskich mitów w nowej oprawie, winno się zwać Torem, „iż tam naprzód była ziemia od ludzi przetorowana" [Dembołęcki 2012: 343], czyli przez protoplastów ludu nadwiślańskiego. Prawie komplet tych uwag nie pozostaje bez związku ze wzmiankowanymi już Malaleelem i Matuzalemem. Wszystko świadczy o etycznej poprawności naszych przodków, ich „pierwszości”, a zwłaszcza o ich militarnej potędze i nadzwyczajnych zdolnościach wojennych.

\section{W stronę ,anektowanych” przodków nacji i państwa polskiego}

Trzeba wreszcie w tym kontekście choćby wspomnieć o najdonioślejszym praszczurze Polaków, o potomku Jafeta, bracie Magoga, mianowicie o Gogu, rozpoznanym w biblijnym Jawanie (gdyż Jafetowi nie urodził się syn o imieniu Gog), wnuku Noego. Zresztą ów Gog-Jawan, niczym Proteusz, mienił się feerią imion, wśród nich m.in. Herkules, Jowisz, Tanaus, Alan. Jest ich kilkadziesiąt, a postać nimi obdarzona w całej tej mozaice genealogicznej z 1633 r. bez wątpienia wypada najbardziej spektakularnie. Skupimy się wszakże wyłącznie na 
jednym, poważnie problematycznym w pewnym sensie, jego mianie. To Baal, idol czczony wbrew i przeciwko Bogu Jahwe [Kopaliński 2003: 73, 97; zob. także Sztyber 2012a: 234], jednakże tę asocjację Dembołęcki zbagatelizował, czapkując polszczyźnie czy przede wszystkim jej szlacheckim użytkownikom, szczycącym się własną profesja, „rycerskim rzemięsłem”. Wyjaśnijmy, dlaczego, a to opinia samego demagoga: „od waleczności tak beł nazwany, same słowa 'bellum', to jest walka i baleczność abo waleczność, także walił abo balił, bił i ból wydają [...] i wszystek świat [się Baala] na on czas bał" [Dembołęcki 2012: 375]. Koligacja to niechlubna, niemniej prostota eksplikacji, przemawiająca klarownością ujęcia, wzięła górę nad zdrowym rozsądkiem i balastem teologicznych zdobyczy. Zgodnie z życzeniem i przerośniętymi ambicjami herbowej rzeszy.

Imię właśnie omówionego bożyszcza zmieściło się, według Dembołęckiego, w łacińskim rzeczowniku określającym ważny rekwizyt w jednej z opowieści Herodota na temat prymatu Scyta (Skytesa) spośród potomstwa Herkulesa i Echidny [Herodot 2008: 231-232]. Językowy odpowiednik tego przedmiotu, „baltheus” [Dembołęcki 2012: 390], przywodzi na myśl zresztą nie tylko samego Baala, ale i jakieś jego parantele z terminem wskazującym... boga [por. Dembołęcki 2012: 401). Ekskluzywne mocno towarzystwo, jak przystało na sarmacką zamaszystość i wyniosłość [por. np. Ziomek 1995: 399]. Zmierzając do finału tego szkicu, wspomina się i ten detal, ponieważ dał asumpt ideologowi do snucia innych rozważań onomastycznych; miały one nadać językowy ślad alternatywnym nazwom Polski, w dwojakim znaczeniu - jako terytorium i państwo. Ponieważ partnerka mitologicznego herosa poczęła naszego praprzodka, jej imię ustalało lingwistyczną sygnaturę kraju, tj. Echidna - ,jakoby Lecha dno abo dziedzina" [Dembołęcki 2012: 282-283]. I Bazylea znajduje tu ojczysty rys. A to nie żadne szwajcarskie miasto. Dembołęcki odtwarza ponoć zagubione brzmienie jego nazwy: „Ważylecha, że ją wszyscy czcili i ważyli”" [Dembołęcki 2012: 282]. Olśniewający obraz legendarnego Lecha zaćmiewał oczy duchownemu albo raczej stał się znakomitym obiektem syntetycznej kpiny z narodu.

W plątaninie „wywodowej” argumentacji właściwie nie pojawia się założyciel Gniezna, jest za to Lach, dość mikry i raczej niesławny protoplasta, przegrał niejedną wojnę, splamił się ucieczką w obliczu zagrożenia, oddał tron Polachowi, tj. Gogowi-Jawanowi, który właśnie po Lagu-Lachu „polagł” „na stolicy świata" [Dembołęcki 2012: np. 367], stąd też następny tytuł wybitnego sukcesora - Poląg. Natomiast jego poprzednika, Lacha-Magoga, duchowny z XVII w. zrównał z Bachusem, Beczkosiem - rzekomo po słowieńsku [Dembołęcki 2012: 324]. Obaj zaś to Kastor i Polluks [Dembołęcki 2012: 367], sławiono ich pieśnią zawierającą wstawkę znaną do dziś: „lelum polelum”, a może „Lelum Polelum” [Dembołęcki 2012: 329, 367]. Więc to Lel i Polel zapewne... Dość wątpliwej reputacji kompania, zapewne podpita [Sztyber, 2012b, 3-20]. „Baltheus”, pas, w translacyjnym maglu Wywodu objawił się jako obrazowy symbol „cięgatury 
władzy" [Dembołęcki 2012: 401], dziedziczenia. Czyżby kwestii nie można było wyjaśnić w inny sposób? Co ciekawe, spadkobiercami krwi tej zaszczytnej linii genealogicznej mieli być Wazowie, importowani przecież królowie, a przynajmniej pierwszy z nich. Jak w tym oświetleniu wolno wierzyć wyrachowanemu mistyfikatorowi?

Zaledwie sygnalnie rejestrujemy przykłady lingwistycznej ekwilibrystyki Dembołęckiego. Ukazują tendencję, pomysł, a także cel traktatu. Są niejako podsumowaniem wielu wcale niełatwych, bo skomplikowanych rekonstrukcji historycznych. Ujawniają równocześnie pozę pisarza, obłudnego i świadomego swoich sprzeniewierzeń doktrynera, usiłującego wmówić, że wszystko, co godne, odznacza się polskim, a co najmniej słowiańskim rytem i proweniencją. Poprzedniczkę Rzeczypospolitej ksiądz obwołał także Pandorą, Szczyciochą. Ponadto - Wandalią, Akwilą (Akwilonem), ostatnia propozycja wydaje się efektem stronniczego odczytania wersetów biblijnych [por. Ulewicz 2006: 157] i potwierdzona literackim konwenansem [por. np. Hussowski 1952: 66; Celtis 1985: 94; Kochowski 1991: 152; zob. też Sztyber 2012a: 178-181], wręcz manierą na definiowanie państwa między Odrą i Bugiem, między Bałtykiem a Karpatami i Sudetami, choć innymi czasy nieco inaczej, rozleglej, wszakże zawsze gdzieś na północy.

Wyjąwszy imiona przywoływanych $\mathrm{w}$ tym szkicu postaci, większość omówionego materiału należy zaliczyć do pomysłów o charakterze makrotoponimicznych modyfikacji. Nie wyczerpują tematu, gdyż np. greckie polis podsunęło Dembołęckiemu cały ciąg ,polskich” skojarzeń, wielbiciel ojczyzny-polszczyzny bowiem imputował czytelnikowi, że znaki językowe, zawierające tę cząstkę, odznaczają się rodzimą genezą, a jest ich „po Azyjej, Afryce i Europie niezliczona rzecz" [Dembołęcki 2012: 370]. Wynotujmy jeszcze dwie osobliwości: Palestyna - Polasczyna, Pelasgia - Polackia. Wszystkie dowodzą, w jakim kierunku postanowił zmierzać twórca i jaką ścieżką podążał. Niekiedy nawet zżymał się na formę łacińskich słów, rzekomo nie dość dostatecznie wyświetlających istotę ich znaczeń. Poglądowa próbka: „wielkie części świata 'plagae' [przestrzeń], jakoby 'polagae' miasto [tj. zamiast] Polakowe królestwo", „ulica - 'platea' [ulica] miasto [j.w.] 'polatea' abo połać" [Dembołęcki 2012: 369-370]. Słowotwory te powstały w hołdzie hołubionemu przez mitomana Polachowi. Wiele z nich przypomina kalambur, inne - rezultat fantazji etymologa ludowego, są też trudniejsze zagadki. Oto egzemplifikacja: „'Sama rama' lubo Semiramis rzeczona [tj. nazwana], [która] sławnym 'Samem żonom' lubo Amazonom początek dała" [Dembołęcki 2012: 365]. W sukurs idzie jednak Nowy Testament, wersety ewangelii mówią o Ramie, mieście, gdzie po utracie dzieci zapłakała Rachela (Mt 2,18). Więc w grę wchodzi po prostu i zabawa słowna, oparta na aluzjach biblijnych (bo i u Jeremiasza proroctwo zapowiada opisane zdarzenie) i wolnych skojarzeniach. 


\section{Zamknięcie}

Z konieczności rozważania te otrzymały mocno skondensowaną postać i stanowią skrótowy rekonesans po pirackich popisach ideowych oraz językowych księdza Wojciecha. Te ostatnie niewątpliwie zasługują na regularne i wnikliwe studium specjalisty, a chyba warto systematycznie przyjrzeć się zagadnieniu, rozpoznanemu dotąd wyłącznie szczątkowo i bez oświetlenia zasadniczych intencji pisarskich, a te wydają się co najmniej dwuznaczne. Brak ich świadomości skazuje naukę na błąd poznawczy bądź daje nadzieję na wyłącznie częściowe poznanie, ostatecznie spłycając rozumienie Wywodu $i$ bagatelizując nie jedno, lecz kilka przesłań traktatu - na pierwszy rzut oka pieszczącego, a w rzeczywistości dotkliwie gryzącego [por. Adalberg 1889-1894: 164]. Z tego też powodu sporo tu miejsca poświęcono woltyżerce myślowej obdarzonego poczuciem humoru franciszkanina [por. Cieślak 2007: 292], w efekcie może nieco odmienne od spodziewanych proporcje prezentacji. Zgłoszony właśnie postulat, a stawia on przed fachowcami zadanie polegające na rozwikłaniu m.in. wielu językowych konceptów Dembołęckiego, niech posłuży jako zamknięcie tego szkicu. Tu warsztat lingwisty z prawdziwego zdarzenia wydaje się niezbędny. Natomiast rezultaty namysłu zapewne okażą się wartościowe historycznie, a ponadto pozwolą zrekonstruować, „jak słowa myślom i uczuciom kłamią [...], dokładniej - jak mogą kłamać”, pisał przy innej okazji J.T. Pokrzywniak [Pokrzywniak 1995: 62].

Bo problem łgarstwa czy obłudy, niestety, nadal pozostaje aktualny. A może „stety”, skoro Ignacy Krasicki w jednym z dygresyjnych fragmentów znakomitej skądinąd Myszeidy - pozbawiając złudzeń co do roli, świadomości i wiedzy pisarza - stwierdzał: „Wierzmy z pospólstwem, a śmiejmy się w ciszy” [Krasicki 1775: 78]. W końcu falsyfikacja to składowa naszej kultury, jedną z nich ostatnio w powieściowej prozie znakomicie opisał U. Eco [Eco 2011], a sam Dembołęcki chętnie korzystał z cudownie ponoć ocalonych pism Berosusa w sfabrykowanej edycji Giovanniego Nanniego [Berosus, Witemberga 1659], niejednokrotnie skrytykowanego za ten niecny czyn już w XVI w., m.in. przez autorytety twórcy rodem z Polski [Sztyber 2012a: 232-234]. Kto jak kto, ale polihistor - kształcony i debiutujący literacko na początku XVII wieku w Krakowie - nie mógł tego nie wiedzieć, przeciwnie - przemilczał drażliwą kwestię, a to kolejny, zupełnie pominięty w tym szkicu, aspekt strategii perswazyjnej Wywodu [por. Kochańska 1956: 130].

\section{Bibliografia}

Adalberg Samuel, 1889-1894, Księga przysłów, przypowieści i wyrażeń przysłowiowych polskich, Warszawa.

Becanus Johannes Goropius, 1569, Joan. Goropii Becani Origines Antwerpianae sive Cimmeriorum Becceselana, Antwerpia. 
Bekanus Johannes Goropius, 1580, Opera Ioannis Goropii Becani [...] Hermathena - Hieroglyphica - Vertumnus - Gallica - Francica - Hispanica, wyd. Laevinus Torrentius, Antwerpia.

Bentkowski Feliks, 1814, Historia literatury polskiej, t. 1, Warszawa-Wilno.

Berosus, 1659, Berosi Sacerdotis Chaldaici antiquitatum libri quinque, Johannes Annius, Wittemberg. Bystroń Jan Stanisław, 1980, Megalomania narodowa, [w:] Jan Stanisław Bystroń, Tematy, które mi odradzano, oprac. i wstęp Leszek Stomma, Warszawa, 277-313.

Celtis Konrad, 1985, O mrozie sarmackim, [w:] Antonina Jelicz (oprac. i wstęp), Antologia poezji polsko-łacińskiej (1470-1543), Szczecin.

Cieślak Stanisław, 2007, O tym, że najdawniejsze jest Królestwo Polskie, a język słowieński pierwotnym językiem świata, „Lignum Vitae” 8, 273-294.

Curtius Ernst Robert, 1997, Literatura europejska i łacińskie średniowiecze, tłum. i oprac. Andrzej Borowski, Kraków.

Dembołęcki Wojciech, 1623, Przewagi elearów polskich, Poznań.

Dembołęcki Wojciech, 2012, Wywód jedynowłasnego państwa świata, Zielona Góra, 277-422.

Eco Umberto, 2011, Cmentarz w Pradze, przeł. Krzysztof Żaboklicki, Warszawa.

Flawiusz Józef, 2001, Dawne dzieje Izraela, tłum. Zygmunt Kubiak, Jan Radożycki, Eugeniusz Dąbrowski, Witold Malej (wstęp), Jan Radożycki (komentarz), Warszawa.

Genebrard Gilbert, 1599, Gilberti Genebrardi Theologi Parisiensis, Divinarum, Hebraicarumque literarum professoris regii, Aquensis Archiepiscopi, Chronographiae libri quator [...], Lyon.

Herodot, 2008, Dzieje, thum. i oprac. Seweryn Hammer, Warszawa.

Hieronim św., 1884, S. Eusebii Hieronymi Stridonensis Presbyteri Liber de nominibus Hebraicis, t. 23, Paryż (Patrologia Latina).

Hussowski Mikołaj, 1952, Pieśń o żubrze, [w:] Marian Plezia (oprac. i wstęp), Najstarsza poezja polsko-łacińska (do połowy XVI wieku), Kraków.

Izydor św., 1911, Isidori Hispalensis episcopi Etymologiarum sive originum libri XX, Wallace Martin Lindsay, t. 1 (ks. 1-10), Oxford.

Jurewicz Kamil, 2007, Wojciech Dębotęcki i jego „, Wywód...”, „Terminus” 1 (16), 279-335.

Justynus Marek Junianus, 1988, Zarys dziejów powszechnych starożytności na podstawie Pompejusza Trogusa [z dodaniem prologów], Ignacy Lewandowski (przeł., wstęp i oprac.), Warszawa.

Kochańska Maria, 1956, Ksiadz Wojciech Dembołęcki z Konojad, Zeszyty Naukowe Uniwersytetu Wrocławskiego, t. 1, Seria A, nr 2, 101-143.

Kochowski Wespazjan, 1991, Parenesis do Korony Polskiej i W[ielkiego] Ks[ięstwa] L[itewskiego] z prognostykiem dobrej nadzieje, [w:] Maria Eustachiewicz (wstęp i oprac.), Wespazjan Kochowski. Utwory poetyckie (wybór), Kraków.

Kopaliński Władysław, 2003, Stownik mitów i tradycji kultury, Warszawa.

Krasicki Ignacy, 1775, Myszeidos, Warszawa.

Ogonowski Zbigniew, 1979, Filozofia i myśl społeczna XVII wieku, cz. 1, wstęp, wyb. i oprac. Zbigniew Ogonowski, Warszawa.

Opaliński Krzysztof, 1953, Satyry, Lech Eustachiewicz (wstęp i oprac.), Wrocław.

Pokrzywniak Józef Tomasz, 1995, Ignacy Krasicki, Poznań.

Puzynina Jadwiga, 1955, Ze staropolskich teorii pochodzenia narodu i języka polskiego (Wojciech Dembołęcki), „Poradnik Językowy” 10, 368-378.

Schedel Hartmann, 1493, Kronika świata, Norymberga.

Stownik tacińsko-polski, 1962, red. Marian Plezia, t. 2, Warszawa.

Szczerbicka-Ślęk Ludwika, 1973, W kręgu Klio i Kalliope, Wrocław 1973.

Sztyber Radosław, 1999, „Banialuki” $i$ „,ambaje”, czyli o pseudoetymologicznej pochwale elearów (lisowczyków), „Studia i Materiały” XLVI, Filologia Polska 10, red. Jerzy Brzeziński, Zielona Góra, 123-142.

Sztyber Radosław, 2010, Do zoila nie-zoila, bo Gryzosława, „Zeszyty Naukowe Uniwersytetu Rzeszowskiego. Seria Filologiczna, Historia Literatury" 5, 42-61. 
Sztyber Radosław, 2011a, Uszlachetnianie prawdy w „Przewagach elearów polskich”, Analecta Literackie i Językowe, t. 2, Proza staropolska, red. Krystyna Płachcińska i Marcin Bauer, Łódź, 191-209.

Sztyber Radosław, 2011b, Wojciech Dembołecki o lisowczykach wierszem i prozq (1620-1621), Warszawa.

Sztyber Radosław, 2012a, „Skqdże to zbłaźnienie świata?” Wojciecha Dembołęckiego „,Wywód jedynowłasnego państwa świata", Zielona Góra.

Sztyber Radosław, 2012b, Z Lelum Polelum przez wieki w strone rodzimej teorii etnogenetycznej z 1633 roku, „Literatura Ludowa”, 3-20.

Tuwim Julian, 1950, Pegaz dęba, czyli panopticum poetyckie, Kraków.

Ulewicz Tadeusz, 2006, Sarmacja. Zagadnienie sarmatyzmu w kulturze i literaturze polskiej, Kraków.

Wiszowaty Andrzej, 1977, Wiersze Andrzeja Wiszowatego do księdza Dębołęckiego, starożytność języka polskiego nad wszystkie całego świata narody wywodzacego, [w:] Poeci polskiego baroku, wstęp, wyb. i oprac. Jadwiga Sokołowska, Kazimiera Żukowska, t. 1, Warszawa, 591-593.

Ziomek Jerzy, 1995, Renesans, Warszawa.

Radosław Sztyber

\section{Around Chosen Dembolęcki's Naming Proposals in the Light of the Treatise [on the Only True Country of the World's] Ideas}

(Summary)

This paper is an attempt of presenting some linguistic games introduced by Dembołęcki in his most known book from 1633. It has been widely criticized for centuries but as it seems wrongly or perhaps even rightly, nevertheless because of improper reasons. There are a lot of various indications suggesting that Dembołęcki was a hypocrite who praised Polish nation in showy manner and only outwardly for - in fact - he denounced obvious defects of the noblemen society. The Dembołęcki's concepts place Poles on the top of nations - in many aspects, as i.a. the oldest people of the globe that should mean possibility of regaining apparently lost rights to rule the whole world. Such an exaggeration must arouse suspicions. The doubts may be also confirmed by peculiar neologisms provided with in the treaty. They appear to be infantile and primitive. Their forms and soundings are thought to reveal "Polish" origins of everything and the entire mankind. However, when analyzing them they become just invented words proving a particular, ideological thesis. For show. There is no need to believe in insinuations stating that e.g. the Greek polis, similar to the name of Dembołęcki's compatriots, indicates Polish cities all over the world. There is no need to believe in sentences glorifying Poles thanks to their mythological ancestor Pollux, the adopted ancestor, the same with biblical Gog and identical with him... Baal, as the writer tried to prove. And finally, there is no need to believe that Sigismund III Vasa, a king of Poland, was a successor of Polish superiority since he was imported from Sweden. Dembołęcki, often confabulating (in this case), created an illusion of truth, supported with lexical "discoveries" revealing alleged sense of well-known and common words. Some of them are ecscerpted, described and discussed in this paper. What is interesting, the author has never identified himself with the opinions printed in Treatise; in a cryptogram contained in the only one poem of the book (ending it) he confessed he did not trust his pen's ink. Besides he opened the main part of his "studies" with a meaning headline: "historical", which had been earlier defined as... just a prattle. These 
naming proposals of Dembołęcki shall have become the author's most innovative and tendentious offers in his persuasive (propaganda to the highest degree) strategy. And language in general and its features must be considered to be one of more effective instrument of his argumentation. Auxiliary - as M. Kochańska convinced, therefore its actual value should be decreased for the all divagations by Dembołęcki nowadays estimated with the lowest notes.

Słowa kluczowe: Wojciech Dembołęcki, literatura baroku, etymologia, megalomania narodowa. Keywords: Wojciech Dembołęcki, Baroque literature, etymology, national megalomania. 